\title{
What is Gained in Subtitling: How Film Subtitles Can Expand the Source Text
}

\author{
Tom Kabara \\ Nagoya University, Japan
}

\section{Introduction}

The problem of translation and loss is a cardinal concern in translation studies. Whenever the topic of translation arises in lay settings, the issue of how much is lost seems quickly to follow. This is especially true in creative genres, such as literary translation, and even more so with genres that place strict constraints on translation strategies, such as audiovisual translations. But what do we mean when we say something is lost in translation? Of course, there are numerous answers to the question, and none are completely satisfying. However, it is probably fair to say that two major concerns with translation are loss of source text meaning and loss of source text "poeticness." For the purpose of this paper, loss of meaning simply refers to the loss of denotative meaning from the source text. Loss of poeticness, on the other hand, refers to a loss of subtlety and nuance that enrich the source text. More specifically, the loss of poeticness means the loss of opportunity for viewers to read beyond the surface, literal meaning of the text and integrate prior knowledge to make inferences about inexplicit meaning in the source text.

One thing translation scholarship can offer is a remedy to this perception that translation must equal loss. Christiane Nord, for example, calls for reframing literary translation from a view that focuses on what is lost to one that emphasizes what is gained. She argues that translation can even promote "growth" of the source text. This same notion can be applied to translation of other types of creative source texts, as well. Indeed, Nord's model can be put to the test by applying it to one of the most constrained forms of translation: interlingual film subtitling. Not only are the subtitles constrained by the subtitling format, which places limits on timing and character counts, but also by more traditional challenges arising in translation of creative source texts. Moreover, Abé Mark Nornes adds ideology to the mix. In his review of Japanese subtitling practices, he argues that the underlying ideology that motivates pervasive domesticating strategies corrupts subtitles. He insists, therefore, that the only solution is a radicalization of subtitling practices (448). This paper, however, will argue that loss and corruption need not be inevitable even in conventional subtitling. By applying Nord's notion of authorship to film subtitling, we can see how translation, even with constraints as severe as subtitling, can make a source text grow.

To test the limits of Nord's idea, this paper will closely analyze Japanese subtitles from a scene in the 2007 film There Will Be Blood. Due to the inherent difference between the two languages, EnglishJapanese translations tend to amplify translational challenges and, therefore, provide a good testing ground for Nord's "growth." Furthermore, this test requires a text dense with dialogue that provides viewers with the opportunity to read beyond the surface and make inferences about text and subtext. 
In other words, there must be ample opportunity for loss of source text meaning and poeticness in the target text. The brief scene selected from There Will Be Blood fits the criteria, and therefore places severe constraints on the translation (i.e., opportunities for loss). Nevertheless, this paper will demonstrate that despite these constraints, the Japanese subtitles actually promote "qualitative growth" of the source text by transferring its poeticness into new configurations in the target text, prompting target text viewers to interpret content in new ways.

\section{Translation that Promotes "Growth"}

Although some translation scholars have made the attempt to connect translation with authorship aesthetically, legally, and socio-politically (Pym 31), conventional views routinely deny the idea that translators produce original content. Perhaps equating translation with conventional notions of authorship is too bold to gain a foothold outside (or even inside) the field, but Christiane Nord takes the term "author" in a slightly different meaning and attempts to rescue translation from being seen as an inherently reductive activity that entails loss. Taking a historical sense of the word "author" that means growth, she applies it to translation and argues that a translator can be considered an author in the sense that he or she is "someone who causes a source text to grow" (22).

One way in which the source text grows, according to Nord, is by quantitative increase in exposure. This quantitative growth refers to the fact that a translation makes a text available to more than just the source culture audience. This brings about new ways of viewing the source text, because, as Nord states, "New and different audiences...facilitate new interpretations" (25). This type of growth is manifest in film subtitling. But the issue is not as simple as more people seeing foreign language films. The act of interpretation is the key here. As shown in the section below, subtitling almost necessarily entails reduction in content. Reduction in content presumably entails reduction in meaning and poeticness, and therefore, a reduction in the opportunity for new interpretations. But this need not necessarily be the case. As the analysis of the subtitles for There Will Be Blood demonstrates, source text meaning can be maintained while the poeticness can be transferred to reach new audiences. Ironically, it is the severe constraints on subtitling that engender this transfer. The constraints force the subtitler to restructure source text language, and it is this restructuring that establishes a new way for audiences to engage with and make inferences about the source text. This is similar to what Nord calls "qualitative growth," which is when new receivers can "even discover "items of the information offer" which were not available to the source-culture audience" (25). The twist here is that instead of "items of the information offer," what is being made available is new opportunities to apply background knowledge to the text which are not available to the source-culture audience. I want to propose that this new way of making inferences about the source text can be considered "qualitative growth" in Nord's sense. 
TranscUlturAl, vol. 7.1 (2015), 166-179.

http://ejournals.library.ualberta.ca/index.php/TC

\subsection{Constraints on Subtitling}

The constraints on the subtitling format make condensing the source text inevitable. Subtitlers can condense the text a number of ways, which include omission and explicitation. Omission can mean loss of meaning and explicitation can mean a loss of poeticness. Thus, such loss stems from not only the inherent limitations of the subtitling format but also the strategies used to cope with those limitations.

In an effort to create a comprehensive framework for audiovisual translation, Henrik Gottlieb proposes that subtitle creation can be thought of as "diagonal translation" as it involves shifting across one semantic channel across to another ("Language" 220). According to Gottlieb, interlingual film subtitles are an example of a diasemiotic translation of a polysemiotic text ("Multidimensional" 36). Here polysemiotic refers to two or more parallel meaning-producing channels constituting a text. In the case of film, three semiotic channels: image (non-verbal), sound (non-verbal), and dialogue produce meaning. Diasemiotic translation refers to "the use of different channels, while the number of channels (one or more) is the same as in the original text," for example, subtitling, which transfers speech sounds into written text (Gottlieb "Multidimensional" 36).

Because subtitling is a diasemiotic translation of a polysemiotic text, the production of subtitles is fraught with a variety of challenges and limitations that force subtitlers to condense the content of the original dialogue. Since subtitles must be synchronized with dialogue and spoken language can be uttered in a shorter amount of time than written words can be read, subtitling imposes limitations on the number of words or characters that can be displayed per second. The standard in Europe and North America is twelve characters per second (CPS) (Pedersen, "A Subtitler's Guide" 47); although this has increased recently to sixteen CPS for DVDs based on the assumption that viewer reading speeds are improving (Gottlieb, "Multidimensional" 51). In Japan, the standard of four CPS was established in the 1930s and remains in force even today. Such character count limitations mean that subtitler must squeeze the entire content of the source text dialogue into a few words or omit some of the content. Rachele Antonini finds that subtitling among European languages results in word count reduction of up to 40 to 75 percent (213). Gottlieb reports that due to this need for such condensation, "language professionals tend to disagree as to whether subtitling is indeed translation, and even the subtitling industry is often reluctant to grant this type of language transfer the status of 'real' translation” (“Language” 219).

Using the same reasoning, practitioners in Japan independently confirm the idea that subtitling does not quite equate to "real" translation. Toda Natsuko', one of the most prolific subtitlers in Japan who is known as the "Queen of Subtitling," states in an autobiographical account of her career that she does not think of subtitling as direct translation of the dialogue but rather as transference of the "essence" of the dialogue (122). Toda's colleague, Ota Naoko corroborates this idea by claiming that "subtitling is not translation but summary" of the dialogue (15). To really drive the point home, in

${ }^{1}$ Japanese names are given in Japanese order, i.e., family name followed by given name. 
1992, Toda published a book of essays by her mentor, Shimizu Shunji, entitled Film Subtitling is not Translation (Eiga jimaku wa honyaku dewa nai). Shimizu insists that what separates translation of books and films is that the film viewer must be able to read the subtitles before they are removed from the screen, and therefore, the subtitles must be brief and readily understood to ensure the audience a satisfying viewing experience (68). This emphasis on easily understood subtitles limits the language subtitlers have at their disposal, especially in a language such as Japanese, which employs ideograms. Indeed, Shimizu warns against using uncommon kanji that could challenge viewers (17). Since kanji is the main means of conveying meaning in Japanese, limiting what kanji can or cannot be displayed limits what can or cannot be expressed.

Thus, the type of translation (diasemiotic) and the strategies deployed specifically for that type of translation place strict constraints on subtitlers. This frequently entails loss of meaning and loss of poeticness as much of the source text must be omitted or made explicit. But this is not always the case. Meaning need not be lost, and, at the same time, the function of source text poeticness can be reestablished by restructuring the source text language.

\section{Condensing the Source Text of There Will Be Blood without Loss of Meaning}

The above principals on Japanese subtitling (emphasis on summarizing the essence of dialogue and use of easily understood language) aim to ensure that at least a sense of the narrative remains available to the target text viewer within the constraints of 4 CPS. The resulting translation is a pared-down, condensed version of the source text. But what exactly is sacrificed? Presumably, the condensation of the source text necessary in subtitling reduces the volume of information on offer: subtitlers must omit much language thus omitting meaning. However, this need not always be the case. A close analysis of the subtitles from a scene from There Will Be Blood demonstrates how subtitles retain denotative meaning while still condensing the source text.

In the scene in question, Paul (Paul Dano), a young rancher, uses a map to explain to oilmen Daniel (Daniel Day-Lewis) and Fletcher (Ciarán Hinds) where they can find oil near his family ranch. The scene is dialogue-driven but the language simple. The content of the dialogue is mostly straightforward conversation about the location of the oil, family composition, and names. With the exception of a handful of lines, traditional translational challenges are few. However, since this is a diasemiotic translation, the target text must be condensed for time. The entire dialogue from this brief scene, the corresponding Japanese subtitles, and a back-translation can be found below (see fig. 1).

Fig. 1. There Will Be Blood (2007) map scene transcript and Japanese subtitles by Matsuura Mina (total run time: 1:45). The lines of dialogue are divided according to their corresponding Japanese subtitles as they appear on the screen. 


\begin{tabular}{|c|c|c|c|c|}
\hline & Chara. & ST Dialogue & TT Dialogue & Back-Translation \\
\hline 1 & Paul & This is us here & ここがうちだ & The house is here. \\
\hline 2 & Paul & $\begin{array}{l}\text { Spur station here at } \\
\text { Little Boston }\end{array}$ & $\begin{array}{l}\text { 支線の駅はリトル・ } \\
\text { ボストン }\end{array}$ & $\begin{array}{l}\text { The spur station is Ritoru } \\
\text { Bosuton }\end{array}$ \\
\hline 3 & Paul & $\begin{array}{l}\text { The Sunday Ranch is } \\
\text { what you're looking } \\
\text { for }\end{array}$ & $\begin{array}{l}\text { その土地は“サンデー } \\
\text { 牧場” }\end{array}$ & $\begin{array}{l}\text { That land is the "Sande- } \\
\text { Ranch" }\end{array}$ \\
\hline 4 & Paul & $\begin{array}{l}\text { There's a sheep trail } \\
\text { that takes you there }\end{array}$ & 羊の道を行けば着く & $\begin{array}{l}\text { If you go on the sheep trail, } \\
\text { you'll arrive }\end{array}$ \\
\hline 5 & Paul & $\begin{array}{l}\text { It's a mile out of town } \\
\text { headed west, not far }\end{array}$ & $\begin{array}{l}\text { 町から西へ } 1.6 \text { キロ } \\
\text { 遠くはない }\end{array}$ & $\begin{array}{l}1.6 \mathrm{~km} \text { westward from the } \\
\text { town, not far }\end{array}$ \\
\hline 6 & Paul & $\begin{array}{l}\text { Just through a small } \\
\text { pass near the base of } \\
\text { the hills }\end{array}$ & $\begin{array}{l}\text { 丘のふもとから山道 } \\
\text { を上がればいい }\end{array}$ & $\begin{array}{l}\text { You should go up the } \\
\text { mountain road from the } \\
\text { base of the hills }\end{array}$ \\
\hline 7 & Paul & $\begin{array}{l}\text { Go past the church } \\
\text { and just follow the } \\
\text { sheep trail }\end{array}$ & $\begin{array}{l}\text { 教会を過ぎ その } \\
\text { まま羊の道を進む }\end{array}$ & $\begin{array}{l}\text { Pass the church and } \\
\text { proceed on the sheep trail as } \\
\text { is }\end{array}$ \\
\hline 8 & Daniel & $\begin{array}{l}\text { Where's Standard } \\
\text { buying up? }\end{array}$ & $\begin{array}{l}\text { スタンダード・オイ } \\
\text { ルが買ったのは? }\end{array}$ & $\begin{array}{l}\text { As for the ones Sutanda-do } \\
\text { Oiru bought? }\end{array}$ \\
\hline 9 & Paul & Here and here & こことここだ & Here and Here \\
\hline 10 & Daniel & $\begin{array}{l}\text { And your family name } \\
\text { is Sunday, yes? }\end{array}$ & $\begin{array}{l}\text { 君の名字はサンデー } \\
\text { か }\end{array}$ & Your family name is Sande-? \\
\hline 11 & Paul & That's right & そうだ & That's right \\
\hline 12 & Daniel & $\begin{array}{l}\text { How many is in your } \\
\text { family? }\end{array}$ & 家族は? & As for family? \\
\hline 13 & Paul & $\begin{array}{l}\text { My father and mother } \\
\text { and sisters and my } \\
\text { brother Eli }\end{array}$ & $\begin{array}{l}\text { 父親と母親 } \quad \text { 妹た } \\
\text { ち 弟のイーラ } \\
\text { イ }\end{array}$ & $\begin{array}{l}\text { My father and mother } \\
\text { younger sisters and brother } \\
\text { I-rai }\end{array}$ \\
\hline 14 & H.W. & $\begin{array}{l}\text { How many sisters do } \\
\text { you have? }\end{array}$ & 妹は何人? & How many sisters? \\
\hline 15 & Paul & Two & 2 人 & Two \\
\hline 16 & Daniel & What's your name? & 君の名は? & As for your name? \\
\hline 17 & Paul & Paul & ポール & Po-ru \\
\hline
\end{tabular}




\begin{tabular}{|c|c|c|c|c|}
\hline 18 & Fletcher & $\begin{array}{l}\text { Does any of your } \\
\text { family know about the } \\
\text { oil that you say is } \\
\text { there? }\end{array}$ & $\begin{array}{l}\text { 家族で石油のことを } \\
\text { 知ってるのは? }\end{array}$ & $\begin{array}{l}\text { As for those who know } \\
\text { about the oil in your family? }\end{array}$ \\
\hline 19 & Paul & $\begin{array}{l}\text { I don't know. My } \\
\text { uncle always said there } \\
\text { was oil there }\end{array}$ & $\begin{array}{l}\text { よ゙うかな 叔父 } \\
\text { は } \\
\text { と石っ油がある } \\
\text { 石っけど }\end{array}$ & $\begin{array}{l}\text { I wonder...My uncle said } \\
\text { there was oil, but }\end{array}$ \\
\hline 20 & Paul & $\begin{array}{l}\text { But I don't know what } \\
\text { they heard or what } \\
\text { they think }\end{array}$ & $\begin{array}{l}\text { その後のことは知ら } \\
\text { ない }\end{array}$ & After that I don't know \\
\hline 21 & Fletcher & What do you grow? & 作物は? & As for crops? \\
\hline 22 & Paul & $\begin{array}{l}\text { It's goats. It' a goat } \\
\text { farm. I told you } \\
\text { nothing grows but } \\
\text { weeds }\end{array}$ & $\begin{array}{l}\text { うはヤギだけ } \\
\text { 言ったろ? } \\
\text { しか育たない }\end{array}$ & $\begin{array}{l}\text { I told you as for us, it's only } \\
\text { goats. Only weeds grow }\end{array}$ \\
\hline 23 & Fletcher & Is there water? & 水は? & As for water? \\
\hline 24 & Paul & $\begin{array}{l}\text { It's salty. You drill a } \\
\text { well, it's hard not to } \\
\text { get salt water }\end{array}$ & $\begin{array}{ll}\text { 塩分が強い } & \text { 井戸 } \\
\text { を掘ると } & \text { 塩水 } \\
\text { が出てくる } & \end{array}$ & $\begin{array}{l}\text { It's salty. If you dig a well, } \\
\text { salt water will come out }\end{array}$ \\
\hline 25 & Paul & The oil is there & 石油はある & There is oil \\
\hline 26 & Paul & I'm telling you & 間違いない & There's no mistake \\
\hline 27 & Paul & I want to go now, so... & じやもう帰る & Well, I'll go home \\
\hline 28 & Daniel & You can stay tonight & 泊まっていけ & Stay \\
\hline 29 & Paul & $\begin{array}{l}\text { No, I want to go now. } \\
\text { I wanna leave }\end{array}$ & $\begin{array}{l}\text { やめておく } \\
\text { たい }\end{array}$ & I'll pass. I want to go home \\
\hline 30 & Daniel & Listen, Paul & $\begin{array}{l}\text { いいか } \\
\text { ル }\end{array}$ & Listen, Po-ru \\
\hline 31 & Daniel & $\begin{array}{l}\text { If I travel all the way } \\
\text { out there and I find } \\
\text { that you've been lying } \\
\text { to me }\end{array}$ & $\begin{array}{l}\text { はるばる出かけてい } \\
\text { き＼cjkstart嘘だったら }\end{array}$ & $\begin{array}{l}\text { If I go all the way out, and } \\
\text { it's a lie }\end{array}$ \\
\hline
\end{tabular}




\begin{tabular}{|c|c|c|c|c|}
\hline 32 & Daniel & $\begin{array}{l}\text { I'm going to find you } \\
\text { and I'm going to take } \\
\text { more than my money } \\
\text { back. Is that alright } \\
\text { with you? }\end{array}$ & $\begin{array}{l}\text { 金を取り返すだけじ } \\
\text { や済まさん } \\
\text { わかってるな? }\end{array}$ & $\begin{array}{l}\text { Taking my money back } \\
\text { won't settle it. Understand? }\end{array}$ \\
\hline 33 & Paul & Yes, sir & はい & Yes \\
\hline 34 & Daniel & Alright then & よろしい & Good \\
\hline 35 & Paul & $\begin{array}{l}\text { Nice luck to you, God } \\
\text { bless }\end{array}$ & 幸運と神の加護を & $\begin{array}{l}\text { Good luck and God be with } \\
\text { you }\end{array}$ \\
\hline \multirow[t]{2}{*}{36} & Daniel & $\begin{array}{l}\text { And to you, young } \\
\text { man }\end{array}$ & 君にもな & You too \\
\hline & & Word Count: 254 & Charact. Count: 389 & Word Count: 195 \\
\hline
\end{tabular}

Although the language of the map scene is simple and highly translatable_-even when working in languages as disparate as English and Japanese-some reduction is necessary due to the subtitling format, and word/character counts for this scene bear this out. As mentioned above, word counts reduce drastically when moving from spoken dialogue to subtitles and There Will Be Blood is no exception. The ST dialogue has a word count of 254, whereas the subtitles have a character count of 389. While the ST word count and TT character count appear similar, they do not reflect the typical calculations found in isosemiotic English-to-Japanese translations. Using the rough but fair estimate of two Japanese characters per English word, we can see that the content has been reduced by approximately one quarter.

The reduction in quantity of content, however, does not amount to a reduction in meaning. Despite the condensed volume of the TT subtitles, there are no major omissions, as the back translation demonstrates. Even culture-specific references (CSRs) - references "connoting different aspects of everyday life such as education, politics, history...place names, foods and drinks...as experienced in different countries and nations of the world" (Antonini, "SAT, BLT" 154)—are retained in the subtitles. Indeed, Matsuura's subtitles preserve the source texts' references to the names of Little Boston and Standard Oil. In other words, the wording in the subtitles may be altered, but all major elements are present. So, how do the subtitles condense the text without omitting source text information? The subtitles feature a mixture of ellipsis and explicitation. Ironically, it is the strategy of explicitation, which makes meaning more precise in the target text that produces the only genuine loss in these subtitles. Although explicitation conveys the meaning of the source text, it simultaneously forfeits poeticness (i.e., the opportunity to make inferences about the source text). Or as Gottlieb puts it, explicitation "may imply sheer banalization of the text, which may in the end lose the very qualities that fascinated the source-language audience, and justified its translation in the first place" ("Texts" 22). 


\section{Explicitation and Loss}

Initially, Olivier Goris noted a tendency toward explicitation in film dubbing translations, but, since then, others have found the same tendency in subtitling (182). According to Jan Pedersen, subtitlers often deploy explicitation as a means of keeping the character counts down while avoiding loss in meaning ("How is Culture" 116-117). In Japanese subtitling, as mentioned above, practitioners aim to summarize the dialogue rather than reproduce it. When faced with oblique language in the source text dialogue, subtitlers make their own interpretation and turn that interpretation into explicit language in the subtitles. Through this process of summarization, subtitlers cannot help but inject their own interpretations quite directly into the target text. As a result, target text viewers are stripped of the opportunity to make their own inferences about the text and produce their own interpretations.

One famous case of explicitation in Japanese subtitling comes from the 1979 film, Apocalypse Now. Author, Tachibana Takeshi, roundly criticized the lack of subtlety in Toda Natsuko's subtitles for the line “Take care of him with extreme prejudice”2, which she rendered as “彼を暗殺せよ” (kare $o$ ansatsu seyo) or simply "Assassinate him" in English. Tachibana was bothered by the inability to capture the euphemistic nature of the original.

In this subtitle, what is lost is not meaning but rather the poeticness of the source text-the subtlety and nuance. The above explicitation strips away the unnerving shadowiness of the source text phrasing. But what is really lost when we relinquish this poetic subtlety? What does the poetic subtlety bring to an audience? It provides an opportunity for the viewer to infer connotative meaning based on context ("terminate command" actually means assassinate) and draw directed conclusions about the characters (these military officers in Vietnam are hypocritical). So when viewers watch the Japanese subtitled version of the scene, they no longer have the opportunity to process in their own minds the source text meaning and produce their own interpretation.

Another thing that can be lost through explicitation in subtitles is the opportunity to discover nuance in the characterizations. We can see this in the map scene from There Will Be Blood. During this scene, Daniel's words and gestures capture ambiguousness to his character that is erased by the subtitles. The muddiness of his intentions is most striking when he raises his hand to Paul in a vaguely threatening manner and says, "If I travel all the way out there and I find that you've been lying to me, I'm going to find you and I'm going to take more than my money back. Is that alright with you?" This enigmatic line along with the sweeping gesture crystallizes Daniel's character in a brief moment. As David Bordwell describes it, "Daniel's characteristic blend of bluff assurance, friendliness, and aggressiveness are packed into this single gesture" ("Hands"). Similarly, his line of dialogue is both polite, inquisitive, and threatening all at once.

\footnotetext{
2 Tachibana's recollection of the line is inaccurate. The actual line from the film is "Terminate the Colonel's command".
} 
The translation of Daniel's key line captures the denotative meaning behind his threat but misses some nuance behind the dialogue. Matsuura's subtitles read: 1. "Harubaru dekaketeiki uso dattara" [If I go all the way out, and it's a lie]/2. "kane wo torikaesu dake ja sumasan wakatte'ru na" [Taking my money back won't settle it. Understand?]. The subtitles capture the vague threat of Daniel, but they fail to replicate the enigmatically polite aggression behind his use of complete sentences and less than coarse language. His final question ("Is that alright with you?") resists the more predictable and rhetorical question that usually comes after this kind of vague threat ("Understand?", "Got it?", etc.). The Japanese subtitles provide the more predictable ending "Wakatte'ru na" ("Understand?”); however, the line in the spoken dialogue is more unusual in that it almost invites a response. Typically, "Is that alright with you?" is used to illustrate a speaker's genuine interest in the opinion of the listener, but that is not the case here. It intimates the illusion of politeness, as do the rest of Daniel's lines and his handshake which is both hostile and well-mannered at once. It may be impossible to create subtitles that capture the mock politeness buried in the use of complete sentences and less than rough language. Complete sentences are probably not an option for Matsuura in this case. Although, it would be easy to reproduce this mock politeness in Japanese (e.g., "Yoroshii deshou ka?"), a phrasing that makes use of honorific forms), that does not necessarily violate guidelines about succinctness in subtitling: the above expression is only one character longer than the one used in the actual subtitles. Perhaps Matsuura feared such juxtaposition would be too jarring. But of course that is the whole point. The character, it would seem, is meant to be enigmatic.

Matsuura's subtitle for this key line acts as an explicitation in the sense that when Daniel says, "Is that alright with you?" he really means "Got it?" in the rhetorical sense. At least, that is one interpretation of the line. And therein lies the essence of loss in subtitling: it is not meaning that is lost, but rather the opportunity to infer meaning. Thankfully, Matsuura provide other opportunities for audiences to exercise their powers of inference in other parts of the scene.

\section{Addition through Subtraction: Semi-Translation and Ellipsis}

While explicitation can strip away the poeticness of a source text, other translation strategies can reproduce its function in new ways. Matsuura's subtitles for the map scene show how well-chosen strategies (that could very well be selected for technical reasons rather than aesthetic) can transfer the opportunity to make inferences about the source text.

\section{Semi-Translation}

As mentioned above culture-specific references (CSRs) to place and company names (Little Boston and Standard Oil), remain intact in the subtitles (lines 2 and 8 respectively). Mastuura elects to transcribe these CSRs into katakana - the Japanese script used primarily for foreign loan words. This strategy can be called "semi-translation" since it performs half the work of a translation. The transcribed terms Ritoru bosuton and Sutanda-do oiru have no direct meaning in Japanese; however, all four of the individual words used are likely to be familiar to viewers in the target culture. The two 
words of the latter subtitle, oiru and sutand-do, are recognized in Japanese dictionaries as discrete words-oiru meaning oil and sutanda-do meaning standard or criterion. Likewise, Bosuton is a city well known enough and every school child in Japan knows the word "little" or its Japanese-transcribed form ritoru. In that sense, these subtitles could be called semi-translation, since they combine recognized Japanese words into unrecognized pairings. Thus, these pairings convey little directly.

To grasp these subtitles, the target text viewer must either call upon previous knowledge about geography or historical oil companies in the U.S. or surmise from the grammatical and narrative context that these terms refer to the names of a place and a company. Naturally, one could say the same thing about source culture viewers as well, but it is not exactly the same as what happens when reading the Japanese subtitles. Source culture viewers can be expected to have the background knowledge to recognize English-language naming patterns, such as the one found in Little Boston, but the same assumption cannot be made of target culture viewers. Because they are rendered in katakana (one of the foremost uses of katakana is for transcribing non-East Asian names), the viewer will immediately recognize that these subtitles likely refer to names, but recognizing that they are names to a town and an oil company requires at least some source culture knowledge and power of inference.

One could make the case that transcribing these CSRs into katakana is the natural choice for a subtitler. If this were a literary translation, this position would be reasonable; however, since this is film subtitling, other strategies could have been used to lessen the burden on readers and avoid disrupting the flow of the subtitles. A common strategy in dealing with CSRs in film subtitling, for example, is to generalize the CSR to a broader category (Chiaro 157). In this case, that would mean generalizing the references to Little Boston to the Japanese word for town, machi, and Standard Oil to oil company, sekiyu gaisha. Using the general term for these two CSRs rather than the lengthy transliterations would reduce the character count by six characters each. Furthermore, in addition to relieving the viewer from reading several more characters in a limited time, generalizing these CSRs would also unburden them from hastily ascertaining their meaning.

But here, Matsuura makes a different move. She does not shy away from challenging viewers and invites them to use previous knowledge of American geography and business to grasp or at least infer the meaning. While this type of inference is perhaps different from the poetic inference required of ambiguous language, it is arguably still similar to the inference required when comprehending subtle meaning. After all, we ask ourselves the same questions when encountering "take care of him with extreme prejudice" or "Ritoru bosuton." Namely, we ask what the speaker's intentions are and why he has chosen those words. The difference lies in what background knowledge we call upon to answer these questions. For the former example, source text viewers rely upon source culture knowledge. Conversely, for the latter example, target text viewers rely upon a combination of source culture and target culture knowledge to decipher meaning. In that sense, we can say that this sort of subtitling can bring qualitative growth to the source text. 


\section{Ellipsis}

Another strategy Matsuura deploys in order to reduce character count and ensure subtitle-spoken dialogue synchrony is ellipsis - the omission of a clause whose meaning is inferable from context. In a number of instances Matsuura elides the ending of lines of dialogue, rendering them as clipped sentence fragments. These elliptical constructions restructure the language of the source text to make the explicit implicit.

Over the course of the map scene, Daniel, Fletcher, and H.W. prod Paul with several questions. These questions are given in complete sentences in the source text. Matsuura condenses them in the subtitles. Specifically, Matsuura utilizes an elliptical construction frequently found in Japanese conversational speech, in which the final part of the sentence is elided and the inquiry ends with the open-ended topic marker $W A$ (は), which can be loosely translated in English as "as for." This kind of elliptical construction thus relies on the context to fill in the rest of the meaning. For example, the subtitle for “Is there water?” (line 23) is “水は?” (mizu wa?), literally, “As for water?” This is a more succinct way to ask about the presence of water than the more literal translation “水はありますか” (Mizu wa arimasu ka) which expands a brief snatch of dialogue into a seven-character subtitle pushing the limits of the four characters per second rule. Matsuura uses the same elliptical constructions to condense the source text at lines 8, 12,16,18, and 21 as well.

Such constructions reduce the quantity of language from the source text, but it would be hard to call the results omissions. In the most literal sense, these constructions are omitting individual words, such as the Japanese for how many, what is, is there, etc. This does create a vagueness to the interaction, but because such vagueness fits in with common modes of interaction in the target culture, the viewer follows the conversation nonetheless. So when Daniel asks Paul, “As for family?" (line 12) in the subtitles, there is little doubt he is asking about the composition of Paul's family (rather than, say, whether his family has joined him on his journey) since content of the question as well as the elliptical phrasing used in the subtitles, are quite common in contexts similar to the one given in the map scene.

The inferential reasoning required to grasp elliptical constructions is quite different from the reasoning necessary for grasping the semi-translations above. For the former, viewers rely on knowledge of the target culture, in other words, conventions of conversational Japanese that have been mapped onto the source text. While this could be considered a domesticating effect, if we compare it to the example of Daniel's vague threat to Paul, we can see that it shares a similar function. The unusualness of Daniel's line "Is that alright with you?" prompts source text viewers to call upon their knowledge of social interaction in the source culture as a way of measuring the sincerity and hostility buried behind this line. Similarly, the above elliptical constructions prompt target text viewers to call forth knowledge about the target culture (what does someone mean when she asks "As for family?" in a Japanese context?) and combine it with their understanding of the text in front of them (Why is Fletcher interested in knowing about water?) to draw inferences about the characters and their 
intentions from the subtitles. This exercises the viewers' powers of inference in a similar way that interpreting Daniel's intentions when saying "Is that alright with you" does. But unlike the source text, it requires viewers to use knowledge of both source text and target culture. Thus, as is the case of semi-translation, this strategy can promote qualitative growth to the source text.

\section{Conclusion}

The constraints on subtitling result in the need to condense source text dialogue, but they do not necessarily result in loss of denotative meaning or poeticness. While it is true certain subtitling strategies, such as explicitation, can strip away poeticness in the name of conveying the source text's denotative meaning, other strategies, such as semi-translation and ellipses, reproduce poeticness from the source text insofar as they prompt target text viewers to make inferences about the ambiguous subtitles in a fashion that is similar to the way source text viewers make inferences about the ambiguous dialogue of the source text. In fact, well-made subtitles can even make the source text grow in the sense that they allow the source text to reach a wider audience and that audience makes inferences to interpret the text calling upon broader background knowledge resources that include both the target culture and source culture. In other words, subtitles require an understanding of both languages and cultures as a matter of course, while the source text need not ask that much of its viewers. Thus, quality subtitles can bring to the source text qualitative growth. 


\section{REFERENCES}

Antonini, Rachele. "The Perception of Subtitled Humour in Italy: An Empirical Study." Humor: International Journal of Humor Research 18.2 (2005): 209-225. Print.

—. "SAT, BLT, Spirit Biscuits, and the Third Amendment: What Italians Make of Cultural References in Dubbed Texts." Doubts and Directions in Translation Studies: Selected Contributions from the EST Congress, Lisbon 2004. Eds. Yves Gambier, Miriam Shlesinger, and Radegundis Stolze. Amsterdam/Philadelphia: John Benjamins Publishing, 2007. 153-167. Print.

Apocalpse Now. Dir. Francis Ford Coppola. Paramount Pictures, 1979. Film.

Bordwell, David. "Hands (and Faces) Across the Table." Weblog post. Observations on Film Art. N.p., 13 Feb. 2008. Web. 12 Feb. 2014.

Chiaro, Delia. "Issues in Audiovisual Translation." Routledge Companion to Translation Studies. Ed. Jeremy Munday. New York: Routledge, 2009. 141-165. Print.

Diaz-Cintas, Jorge, Aline Ramael. Audiovisual Translation: Subtitling (Translation Practices Explained). Manchester: St. Jerome, 2007. Print.

Goris, Olivier. "The Question of French Dubbing: Towards a Frame for Systematic Investigation.” Target 5.2 (1993): 169-190. Print.

Gottlieb, Henrik. Subtitles, Translation and Idioms. Copenhagen: Center for Translation Studies and Lexicography, University of Copenhagen, 1997. Print.

. "Texts, Translation and Subtitling - In Theory, and in Denmark". Translators and Translations. Eds. Henrik Holmboe and Signe Isager. Denmark: Aarhus University Press, 2001. 149-192. Print.

—. "Language-Political Implications of Subtitling". Topics in Audiovisual Translation. Ed. Pilar Orero. Amsterdam: John Benjamins Publishing, 2004. 83-100. Print.

. "Multidimensional Translation: Semantics turned Semiotics." MuTra: Challenges of Multidimensional Translation-Saarbrücken 2-6 May 2005. Eds. Heidrun Gerzymisch-Arbogast and Sandra Nauert. Saarbrücken: Advanced Translation Research Center, Saarland University, 2005. 33-61. Print.

Natsuko, Toda. Jimaku no naka no jinsei. Tokyo: Hakusuisha, 1997. Print. 
Nord, Christiane. "Making the Source Text Grow: A Plea Against the Idea of Loss in Translation." The Translator as Author: Perspective on Literary Translation. Eds. Claudia Buffagni, Beatrice Garzelli, and Serenella Zanotti. Berlin: LIT Verlag, 2011. 29-30. Print.

Nornes, Abé Mark. "For an Abusive Subtitling." The Translation Studies Reader. Ed. Lawrence Venuti. New York: Routledge, 2004. 447-469. Print.

Ota, Naoko. Jimakuya wa ginmaku no katasumi de nihongo ga hen da to sakebu. Tokyo: Kobunsha, 2007. Print.

Pedersen, Jan. "How is Culture Rendered in Subtitles." MuTra: Challenges of Multidimensional Translation-Saarbrücken 2-6 May 2005. Eds. Heidrun Gerzymisch-Arbogast and Sandra Nauert. Saarbrücken: Advanced Translation Research Center, Saarland University, 2005. 113-130. Print.

—_. “A Subtitler's Guide to Translating Culture.” Multilingual 20.3 (2009): 44-48. Print.

Pym, Anthony. "The Translator as Non-Author, and I am Sorry about That." The Translator as Author: Perspective on Literary Translation. Eds. Claudia Buffagni, Beatrice Garzelli, and Serenella Zanotti. Berlin: LIT Verlag, 2011. 31-44. Print.

Shimizu, Shunji,. Eiga jimaku wa honyaku de wa nai. Eds. Natsuko Toda and Ueno Tamako. Tokyo: Hayakawa Shobo, 1992. Print.

Tachibana, Takeshi. "Jigoku no mokushiroku kenkyu." Shokun. 1 April 1980. Print.

There Will Be Blood. Dir. Paul Thomas Anderson. Paramount, 2007. Film. 